through geological time $e^{6, y, 10}$ by mechanisms also interpretable in terms of global tectonics.

Apart from the mechanical difficulties in quantitatively subducting continental detritus ${ }^{11}$ and then mixing it completely with the mantle, there is much geochemical and isotopic evidence that the source regions of oceanic basalts have been heterogeneous for $\sim 1,500 \mathrm{Myr}$ or more ${ }^{12,13}$. Considerations of diffusion parameters suggest that large-scale mantle mixing is implausible $^{14}$. Furthermore, in the absence of selective crustal isotopic contamination, isotopic data from many Phanerozoic and modern island-arc and continental margin calc-alkaline igneous rocks clearly indicate an origin from source regions within upper mantle and/or subducted basic lithosphere with little or no contribution of continental detritus with average crustal $\mathrm{Rb} / \mathrm{Sr}$ values $^{13,16}$. Indeed, this seems to be consistent with a recent paper by Windley and Smith $^{17}$, in which close analogy is drawn between igneous rocks formed at modern destructive plate margins and high-grade gneiss complexes of Archaean age.

$I$ interpret much of the evidence to suggest that the bulk of juvenile continental crust has been produced throughout geological time (possibly episodically) from mantle, or basic lithosphere, that have not previously mixed to any significant extent with continental crust $^{\mathrm{B}, 18}$. It is likely that the inconsistent evidence quoted by Windley ${ }^{1}$ will soon be superseded by age and isotope data capable of yielding a truly quantitative measure of continental growth in any given area, as foreseen in the pioneering work of Hurley et al. ${ }^{14,20}$.

\section{S. MOORBATH}

\section{Department of Geology and Mineralogy,}

\section{University of Oxford, Oxford, UK}

1. Windley, B. F. Nature 270, 426-428 (1977)

2. Hargraves, R. B. Science 193, 363-371 (1976).

. Allaart, $J$. H. in The Early History of the Earth 1976).

4. Michard-Vitrac, A., Lancelot, J., Allègre, C. J. \& Moorbath, S. Earth planet. Sci. Lett. 35, 449-453 (1977).

5. Moorbath, S., Allaart, J. H., Bridgwater, D. \& McGregor, $\ddot{V}$. R. Nature 270, 43-4S (1977).

6. Moorbath, S. Chem. Gcol. 20, 151-187 (1977).

Shaw, D. M. in The Early History of the Earth (ed. Windley, B. F.) 33-53 (Wiley, London, 1976).

8. Fyfe, W. S. Phil. Trans. R. Soc. A280, 655-660 (1976).

9. Ringwood, A. E. J. geol. Soc. Lond. 130, 183-204 (1974).

10. O'Nions, R. K., Evensen, N. M., Hamilton, P. J. \& Carter, S. R. Phil. Trans. R. Soc. A. (in the press) 1. Karig, D. E. \& Sharman, G. F. Bull. geol. Soc. Am 86, 377-389 (1975).

12. Brooks, C., Hart, S. R., Hofmann, A. \& James, D. E. Earth planet. Sci. Lett. 32, 51-61 (1976).
Hanson, G. N. J. geol. Soc. Lond. 134, 235-253 (1977).

14. Hofmann, A. \& Hart, S. R. Yb. Carnegie Instn Wash. 74, 195-210 (1975)

15. Meijer, A. Bull.geol. Soc. Am. 87, 1358-1369(1976). planet. Sci. Lett. 37, 197-202 (1977).
17. Windley, B. F. \& Smith, J. V. Nature 260, 671-675

18. Moorbath, S. Phil. Trons. R. Soc. A. (in the press). Hurley, P. M., Hughes, H., Faure, G., Fairbairn. H. W. \& Pinson,

0. Hurley, P. M. \& Rand, J. R. Science 164, 12291242 (1969).

\section{Failure of acids to eliminate aziridinyl residues in chemosterilised mosquitoes}

THIOTEPA and several of its analogues chemosterilise male mosquito pupae, but the use of these compounds in the field has been restricted because of the presence of mutagenic residues inside the pupae. We were therefore interested in Sharma's ${ }^{1}$ proposal for eliminating mutagenic residues of chemosterilant inside mosquito pupae. Providing no chemical documentation, he proposed that chemosterilised pupae should be soaked in $0.0025 \mathrm{~N}$ $\mathrm{H}_{2} \mathrm{SO}_{4}$ for $90 \mathrm{~min}$, and based his proposal on the unstable nature of thiotepa (and its analogues) in media of low $p \mathrm{H}$. We investigated the proposed method by using a gas chromatograph equipped with a flame photometric detector to confirm the levels of residues of an analogue of thiotepa in chemosterilised pupae after treatment in $\mathrm{H}_{2} \mathrm{SO}_{4}$. We found that the method had no detectable effect on residues of the chemosterilant inside the pupae.

We used a $1 \%$ aqueous solution of $P, P$-bis(1-aziridinyl)- $N$-methylphosphinothioic amide (referred to as A13-61585) to sterilise pupae of the mosquito Anopheles albimanus. Exposure of pupae for $1 \mathrm{~h}$ in a $1 \%$ solution consistently induced more than $99 \%$ sterility in males of A. albimanus $^{2}$. We used the methods of Seawright et $a l^{2}{ }^{2}$ to rear mosquitoes, extract the residues and conduct gas chromatographic analysis. The column $(4 \mathrm{~mm}$ inner diameter) was packed with $3 \% \mathrm{OV}-225$ on Gas Chrom Q 100-120 mesh. A flame photometric detector was operated in the phosphorus mode using a 525-nm filter and a solvent bypass valve.

In preliminary experiments, we noted that formulation of a $1 \%$ solution of A13-61585 in $0.01 \mathrm{~N} \mathrm{H}_{2} \mathrm{SO}_{4}$ caused complete degradation of the chemosterilant within $10 \mathrm{~min}$. This observation was consistent with Sharma's bioassay results". However, there was no quantitative difference in the residues of A13-61585 in chemosterilised pupae soaked either in $0.01 \mathrm{~N} \mathrm{H}_{2} \mathrm{SO}_{4}$ for $1 \mathrm{~h}$ or in distilled water. In further tests the chemosterilised pupae were soaked in $0.1 \mathrm{~N} \mathrm{H}_{2} \mathrm{SO}_{4}$ or $0.1 \mathrm{~N} \mathrm{HCl}$ for $1-4 \mathrm{~h}$. The internal residues of A13-61585 were statistically equal in the acid-treated and control pupae. As there was no apparent degradation of chemosterilant within the pupal tissue, we added up to 1,000 p.p.m. of dimethylsulphoxide (DMSO) to a few acid solutions in an attempt to enhance penetration of the insect cuticle and to decrease surface tension. However, the addition of DMSO had no effect on internal residues of A13-61585.

Our final experiment with $0.01 \mathrm{~N}$ and $0.1 \mathrm{~N} \mathrm{H}_{2} \mathrm{SO}_{4}$ is summarised in Table 1 , and the data are representative of all our observations. Soaking the chemosterilised pupae in acidic media clearly had no effect on levels of internal residues of A13-61585. The acid probably does not penetrate the cuticle of the pupae because of the highly polar nature of strong acids. We feel that similar observations would be obtained with closely related analogues of A1361585 , such as thiotepa.

Table 1 Amounts of A13-61585 found in pupae of Anopheles albimanus

\begin{tabular}{cccc}
\hline \multicolumn{2}{c}{ Treatment time (h) } & $\begin{array}{c}\text { ng A13-61585 } \\
\text { per pupa }\end{array}$ \\
$0.1 \mathrm{~N}$ & $0.1 \mathrm{~N}$ & & \\
$\mathrm{H}_{2} \mathrm{SO}_{4}$ & $\mathrm{H}_{2} \mathrm{SO}_{4}$ & $\mathrm{H}_{2} \mathrm{O}$ & \\
& 1 & & $40.3 \pm 4.9$ \\
& & & $52.2 \pm 2.5$ \\
& 3 & 1 & $49.3 \pm 7.2$ \\
& & 3 & $34.0 \pm 4.8$ \\
& & $34.0 \pm 6.8$ \\
\hline
\end{tabular}

Pupae were treated in a $1 \%$ solution of the aziridinyl sterilant for $1 \mathrm{~h}$ and then held in $\mathrm{H}_{2} \mathrm{SO}_{4}(0.01-0.1 \mathrm{~N})$ or $\mathrm{H}_{2} \mathrm{O}$ for $1-3 \mathrm{~h}$. Each mean is the average of three samples each with 200 pupae.

Although our data contradict Sharma's conclusion, the idea of using a chemical to degrade chemosterilant residues deserves more inquiry. There are two necessary requirements for such a compound; first, it must penetrate the cuticle of a mosquito pupa, and second, it must react with the chemosterilant to produce innocuous products. Penctration of the cuticle is related to the polarity of the compound, and relatively non-polar substances penetrate to a greater extent than do polar substances. For degradation of the chemosterilant, the compound should have groups that react with the ethyleneimine moieties. We have initiated a screening programme to find a compound that will perform these two functions without severe impairment of the vigour of chemosterilised males.

\author{
J. A. Seawright \\ D. A. CARLSON \\ Insects Affecting Man and Animals \\ Research Laboratory, \\ $S E A, U S D A$,
}

P.O. Box 14565 , Gainesville, Florida 32604

\section{K. D. KONYHA}

Department of Entomology \& Nematology, University of Florida,

Gainesville, Florida 32611

1. Sharma, V. P. Nature 261, 135 (1976).

2. Seawright, J, A., Bowman, M. C. \& Lofgren, C. S. J. econ. Ent. 66, 305-308 (1973). 